\title{
Molecular Analysis of Immune-Escape Mutants of Hepatitis B Virus from Local Clinical Samples
}

\author{
CHANDRA JINATA ${ }^{1}$, ERNAWATI ARIFIN GIRI-RACHMAN ${ }^{1}$, AND \\ DEBBIE SOEFIE RETNONINGRUM ${ }^{2} *$
}

\author{
${ }^{1}$ School of Life Sciences and Technology, Institut Teknologi Bandung, \\ Jalan Ganesha 10, Bandung 40132, West Java, Indonesia; \\ ${ }^{2}$ School of Pharmacy, Institut Teknologi Bandung, Jalan Ganesha 10, Bandung 40132, West Java, Indonesia
}

\begin{abstract}
Small hepatitis B surface antigen ( $\mathrm{sHBsAg}$ ) is used as a component of hepatitis B vaccine. Even though this vaccine is known to be effective in preventing hepatitis B disease, natural mutation may induce Hepatitis B Virus (HBV) to form immune-escape mutant. This mutant is not only capable of infecting hepatitis B-vaccinated people, but also causing commercial diagnostic assay failure. Immune-escape mutant is generally detected from amino acid change at Major Hydrophilic Region (MHR) of sHBsAg while the change occurred outside the region may also lead to immune-escape mutant formation. This research was aimed to investigate the presence of HBV immune-escape mutants in local clinical samples in Indonesia. sHBsAg gene of seventeen HBV samples from local patients were amplified by polymerase chain reactions then subjected to two-directional sequencing. The DNA sequences later were analyzed by bioinformatics programs. Fifteen out of seventeen samples were genotype $\mathrm{B}$ and subtype adw2, while the other two were genotype $\mathrm{C}$ and subtype adrq + . Among fifteen genotype B samples, twelve of them were not immune-escape mutants, two were immune-escape mutants that have been previously reported (Gln129Arg and Met133Leu), and one was a mutant outside MHR that has not been previously reported as an immune-escape mutant (Tyr161Ser). Both samples of genotype C group were not immune-escape mutants. As conclusion, by investigating seventeen local clinical HBV samples, it was known that two of seventeen samples were confirmed as immune-escape mutants and one of seventeen samples was a mutant outside MHR.
\end{abstract} antigen

Key words: hepatitis B virus, immune-escape mutant, major hydrophilic region, small hepatitis B surface

Antigen permukaan berukuran kecil dari virus hepatitis $\mathrm{B}(s H B s A g)$ digunakan sebagai salah satu komponen vaksin hepatitis B. Meskipun vaksin ini diketahui efektif dalam mencegah penyakit hepatitis B, namun mutasi alami pada virus hepatitis B $(H B V)$ dapat menginduksi terbentuknya mutan lolos imun. Mutan ini selain dapat menginfeksi orang-orang yang sudah divaksinasi hepatitis B sebelumnya, juga mengakibatkan kegagalan deteksi oleh kit diagnostik komersial. Mutan lolos imun biasanya dideteksi dari perubahan asam amino pada Major Hydrophilic Region (MHR) dari $s H B s A g$, meskipun perubahan asam amino di luar daerah ini juga dapat mengakibatkan pembentukan mutan lolos imun. Penelitian ini bertujuan untuk mempelajari keberadaan mutan lolos imun HBV pada sampel klinis lokal di Indonesia. Gen sHBsAg pada tujuh-belas sampel $H B V$ dari pasien lokal diamplifikasi dengan reaksi polimerisasi berantai kemudian disekuensing pada dua arah pembacaan. Sekuens DNA yang didapat kemudian dianalisis dengan program bioinformatik. Lima-belas dari tujuh-belas sampel termasuk genotipe B dan subtipe adw2, sementara dua lainnya termasuk genotipe C dan subtipe adrq + . Pada lima-belas sampel genotipe B, dua-belas di antaranya bukan termasuk mutan lolos imun, dua termasuk mutan lolos imun yang sudah dilaporkan sebelumnya (Gln129Arg dan Met133Leu), dan satu termasuk mutan di luar MHR yang belum dilaporkan sebelumnya sebagai mutan lolos imun (Tyr161Ser). Kedua sampel dari genotipe $C$ bukan termasuk mutan lolos imun. Sebagai kesimpulan, berdasarkan hasil investigasi tujuhbelas sampel klinis lokal $H B V$, diketahui bahwa dua dari tujuh-belas sampel termasuk mutan lolos imun dan satu dari tujuh-belas sampel termasuk mutan di luar $M H R$.

Kata kunci: antigen permukaan berukuran kecil dari virus hepatitis $\mathrm{B}(s \mathrm{HBs} \mathrm{Ag})$, major hydrophilic region, mutan lolos imun, virus hepatitis B

Hepatitis B Virus (HBV) is one of the most common infectious disease causing agents in the world. This virus was estimated to infect one third of total world population and approximately around $20 \%$ of them are infected chronically (Chan et al. 2011). Not

*Corresponding author, Phone/ Fax: +62- 22- 2504852, E-mail: retnoningrum@indo.net.id only causing chronic infection, this virus can also induce liver cirrhosis and hepatocellular carcinoma formation. As an early stage in preventing $\mathrm{HBV}$ infection, small hepatitis B surface antigen (sHBsAg) is used as a major component of hepatitis B vaccine (Mast et al. 2005; Clements et al. 2010; Chan et al. 2011). Furthermore, to control HBV infection in postexposure stage, chemotherapeutic agents such as 
interferon- $\alpha$ and nucleoside or nucleotide analogs are used in combinations with different effectiveness and results (Mast et al. 2005; Glebe 2007).

Even though there are strategies in controlling $\mathrm{HBV}$ in pre- and post-exposure stages, HBV is still one of the most difficult infectious agents to defeat since the virus is variable due to the intrinsic activity of HBV DNA polymerase that results in high rate of natural mutations. The high variability of HBV is shown by the coexistence of different viral population in various proportions. Moreover, different environmental conditions also determine variant compositions of the population that occurs during HBV infection. HBV immune-escape mutant is the result of natural mutation that occurred on the small hepatitis B surface antigen coding gene and its existence is also supported by selection pressure of both hepatitis B vaccine (vaccineinduced escape mutant) and nucleoside or nucleotide analogs which affect not only HBV polymerase gene structure directly, but also its overlapped gene-the surface antigen gene-structure indirectly (Pawlotsky 2005; Cuestas et al. 2006; Valsamakis 2007; Clements etal.2010).

HBV immune-escape mutant is a variant of HBV that cannot be recognized by neutralizing antibody because its antigenicity profile has changed due to the mutation (Pawlotsky 2005; Glebe 2007). This mutant is related to clinical cases such as occult hepatitis B infections, reactivation of hepatitis B, and diagnostic assay failure (Purdy 2007). Immuneescape mutant issue becomes more and more urgent since its variability has been increasing with time and associated with the development of hepatocellular carcinoma (Carman 1997; Purdy 2007; Salpini et al. 2011). About $3 \%$ of total HBV infections was HBV immune-escape mutant cases in China ( $\mathrm{He}$ et al. 2001).

Generally, mutation on the Major Hydrophilic Region (MHR) of sHBsAg coding gene, especially on antigenic ("a") determinant or epitope, causes the induction of HBV immune-escape mutant generation. Moreover, amino acid change outside MHR also affects epitope conformation of sHBsAg (Weinberger et al. 2000; Purdy 2007). This research was aimed to investigate the presence of HBV immune-escape mutants in local clinical samples in Indonesia. In this study, we observed the presence of HBV immune-escape mutants from local patients in Indonesia and analyzed the amino acid change and its effect to the physical profile of sHBsAg by bioinformatics prediction tools.

\section{MATERIALS AND METHODS}

PCR and DNA Sequencing. Seventeen HBV DNA samples were isolated at Pramita Diagnostic Laboratory, Jakarta, Indonesia. The sHBsAg gene was amplified by PCR using primers designed by Kusumawardhani (2009) for forward sequence and Utari (personal communication 2011) for reverse sequence. The nucleotide sequences of the primers were as follows: F:5'-GAATTCATGGAGAACATCG CATCAGG-3' and R:5'-GGTCACCTTAAATGTATA CCCAAAGAC-3'. The PCR mixture contained $1 \mu \mathrm{L}$ genomic DNA template, final concentration of: 1 X Taq buffer, $2 \mu \mathrm{M} \mathrm{MgCl}_{2}, 0.2 \mathrm{mM}$ dNTPs, $0.2 \mathrm{U}$ Taq DNA polymerase, and $0.4 \mu \mathrm{M}$ of each primer per $25 \mu \mathrm{L}$ reaction. The PCR program consisted of predenaturation at $94^{\circ} \mathrm{C}$ for $2 \mathrm{~min}$, followed by 30 cycles at $94{ }^{\circ} \mathrm{C}$ for $30 \mathrm{sec}, 55^{\circ} \mathrm{C}$ for $45 \mathrm{sec}$, and $72{ }^{\circ} \mathrm{C}$ for $1 \mathrm{~min}$. The last step was at $72{ }^{\circ} \mathrm{C}$ for $7 \mathrm{~min}$. As positive control, sHBsAg gene-containing-plasmid BamAFSV from Zainuddin (2008) was used. PCR results were visualized by electrophoresis on $1.2 \%(\mathrm{w} / \mathrm{v})$ agarose gel in $1 \mathrm{X}$ TAE, followed by gel immersion in diluted ethidium bromide $\left(0.5 \mu \mathrm{g} \mathrm{mL}^{-1}\right)$. Positive result was based on the presence of DNA band of $681 \mathrm{bp}$ on the agarose gel. Specific DNA band later was purified by Gel or PCR DNA Fragments Extraction Kit (Geneaid) then subjected to two-directional direct sequencing at $1^{\text {st }}$ Base Company, Singapore.

Sequence Analyses. Raw sequences from direct sequencing were confirmed by contig analysis and BLAST-n (http://www.ncbi.nlm.mih.gov/blast). Genotyping was based on the similarities to DNA sequence references in GenBank NCBI (http://www.ncbi.nlm.nih.gov). Each sample sequence was aligned to a conserved sequence based on alignment of sHBsAg coding genes deposited in the GenBank NCBI database. Mutation and amino acid change analyses were performed by BioEdit Program (http://www.mbio.ncsu.edu/bioedit) and later each of mutant sHBsAg amino acid sequence was analyzed further on B Cell Epitopes Prediction Program utilizing Emini Surface Accessibility Prediction, Kolaskar and Tongaonkar Antigenicity, Parker Hydrophilicity Prediction, and Bepipred Linier Epitope Prediction Tools Program (http://tools.immuneepitope.org).

\section{RESULTS}

PCR, DNA Sequencing, and Sequence Analyses. Amplified DNAs from PCR migrated 


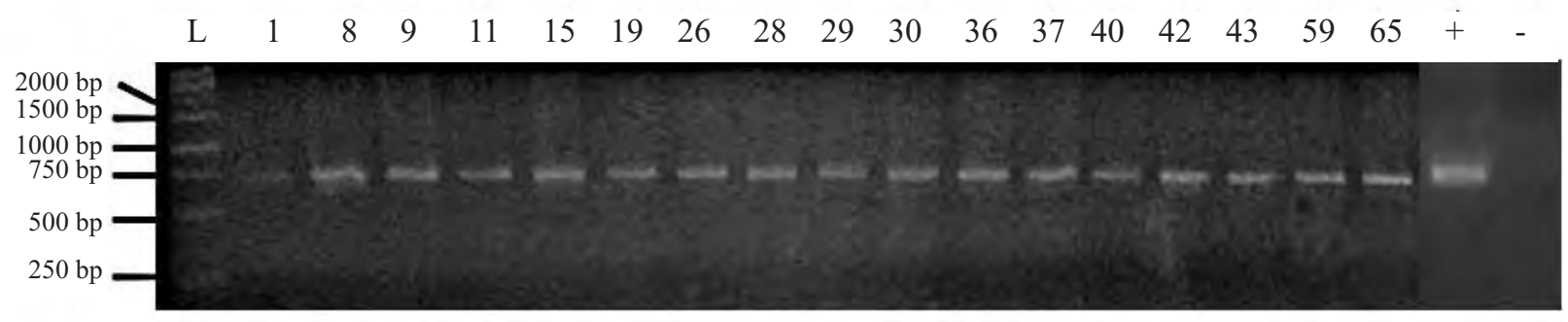

Fig 1 Electrophoregram result from seventeen amplified DNA samples. The DNAs were migrated around $680 \mathrm{bp}$, indicating the presence of sHBsAg genes (681 bp). Notes: L: DNA ladder $1 \mathrm{kbp}$; number listed above is sample number; - : negative control.

Table 1 Index changes of B Cell Epitopes from three mutants showed amino acid change causes different index between wild-type and mutant

\begin{tabular}{ccccc}
\hline Mutant & ESAP & KTA & PHP & BLEP \\
\hline Gln129Arg & $2,511 \rightarrow 2,819$ & $0.978 \rightarrow 0.958$ & $4,686 \rightarrow 4,429$ & $1,376 \rightarrow 1,204$ \\
Met133Leu & $1,666 \rightarrow 1,395$ & $0.970 \rightarrow 1,030$ & $1,800 \rightarrow 1,086$ & $0.438 \rightarrow 0.290$ \\
Tyr161Ser & $2,306 \rightarrow 1,984$ & $1,034 \rightarrow 1,013$ & $-2,100 \rightarrow-0.900$ & $-0.959 \rightarrow 0.599$ \\
\hline
\end{tabular}

ESAP: Emini Surface Accessibility Prediction; KTA: Kolaskar and Tongaonkar Antigenicity Prediction; PHP: Parker Hydrophilicity Prediction; BLEP: Bepipred Linier Epitope Prediction.

around $680 \mathrm{bp}$-long of DNA ladder of $1 \mathrm{kbp}$ in the agarose gel electrophoresis, indicating the presence of 681 bp-long sHBsAg genes (Fig 1). After the DNAs were sequenced, partially confirmed DNA sequences from each sample were obtained (GenBank NCBI accession number: JQ646056-646072). Based on high similarity score (99\%) to DNA sequence references in GenBank NCBI, fifteen out of seventeen samples were found to be genotype $\mathrm{B}$, while the other two belonged to genotype C. Using HBV subtype determination algorithm (Purdy 2007), all genotype B samples were known to be subtype adw2 and all genotype $C$ samples belonged to subtype adrq + . Twenty-seven HBV full genome DNA sequence references from GenBank NCBI were used to obtain a conserved sHBsAg coding gene from genotype B and C. Utilizing the conserved sequences, mutation and amino acid change analyses were performed. Among fifteen samples from genotype B pool, twelve of them were not immune-escape mutants, two of them were immune-escape mutants (accession number JQ646059 and JQ646069) and which have previously been reported (Met133Leu and Gln129Arg, respectively), and one was both a mutant with amino acid change outside its MHR (accession number JQ646056) and has never been reported as an immune-escape mutant (Tyr161Ser).

B Cell Epitopes Prediction Program Analysis. sHBsAg amino acid sequences from wild-type and 3 mutants were analyzed by the four tool programs. Table 1 showed that compared to the wild-type, amino acid change from each mutant also caused different amino acid index specifically to the designated amino acid. Fig 2 showed different antigenic propensity between wild-type and mutants in amino acid 101-161 of sHBsAg based on Kolaskar and Tongaonkar antigenicity prediction tool, while Fig 3 represented the different antigenic score between wild-type and mutants in amino acid 101-161 of sHBsAg based on Bepipred linier epitope prediction tool.

\section{DISCUSSION}

Based on this research, HBV genotype B was found more dominant (88.2\%) than the genotype $\mathrm{C}$ $(11.8 \%)$ in this study. This result was supported by Thedja et al. (2011) who found that HBV genotype B is more common in Indonesia, especially in the western and southern part. As genotype of HBV is correlated to its infection severity, $\mathrm{HBV}$ genotype $\mathrm{C}$ is known to be more progressive in enhancing clinical phenotype to form hepatocellular carcinoma (Zumbika et al. 2005; Aljarallah 2006). Assuming that all patients had the same genetic background, this result suggests that probability of hepatocellular carcinoma formation that caused by HBV infection on Indonesian patients may be lower than in the region where HBV genotype $\mathrm{C}$ is dominant. As for HBV subtype, in this research HBV genotype B subtype adw2 was found highly predominant and two samples of HBV genotype $\mathrm{C}$ belonged to subtype adrq + . This result was supported 


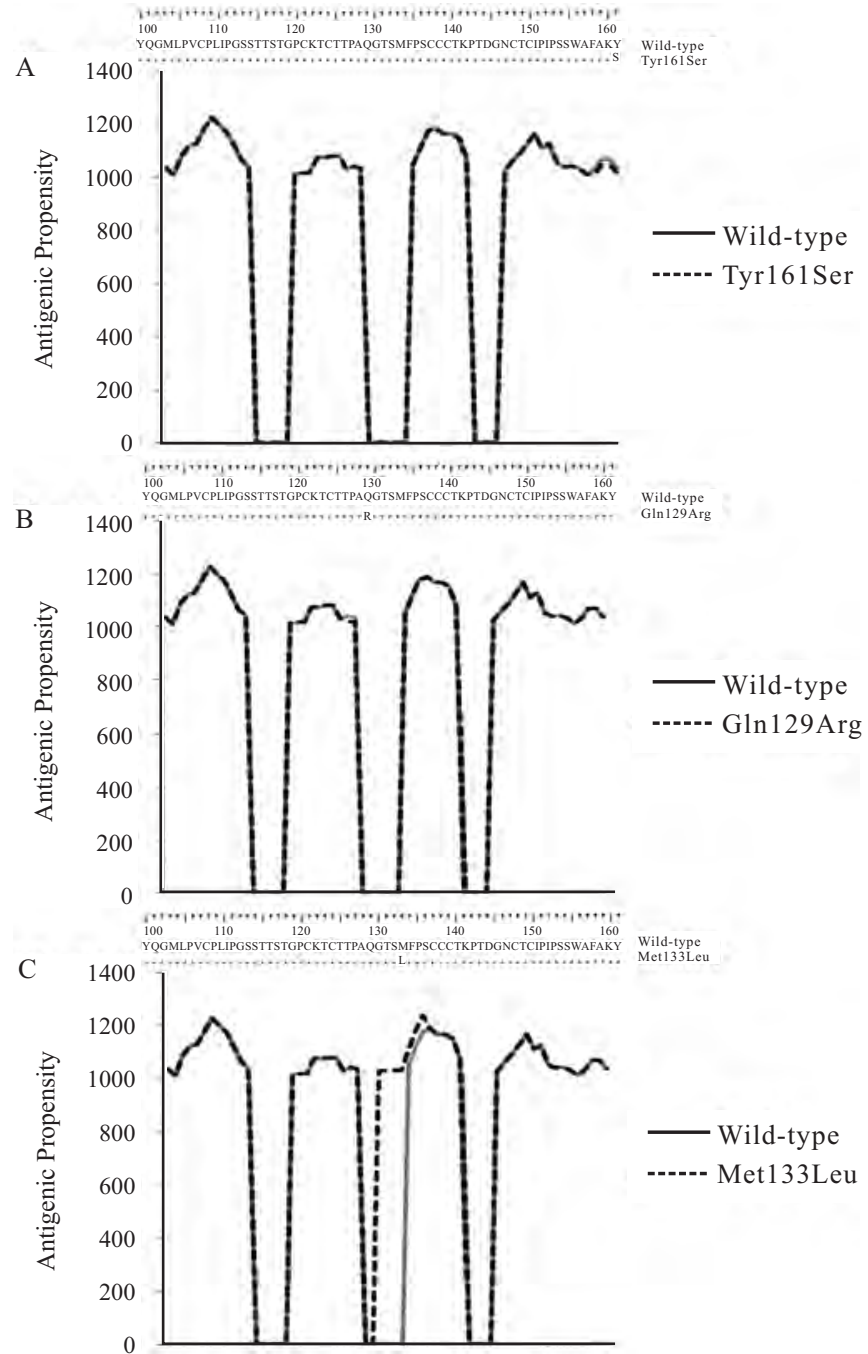

Fig 2 Kolaskar and Tongaonkar antigenicity prediction results from mutant Tyr161Ser(A), Gln129Arg (B), and Met133Leu (C). Mutant Tyr161Ser and Gln129Arg showed minor difference of antigenic propensity in amino acid 158-161 and 127-128 of sHBsAg respectively compared to wild-type, while mutant Met133Leu gave major difference of antigenic propensity in amino acid 129-136 of sHBsAg compared to wild-type.

by Lusida et al. (2008) who represented that in Indonesia HBV genotype B subtype adw2 has been known to be predominant in Sumatera, Java, the southern part of Borneo, Bali, Lombok, Ternate, and Morotai while HBV genotype C subtype adrq+ was found mostly in Papua.

Three mutants that were found in this research-two of them were known as immune-escape mutants-were from HBV genotype B. Based on the multiple reference sequence alignment of sHBsAg coding sequence from HBV genotype B and C (data not shown), it was known that genetic variability was more common present on the genotype B. This result may suggest that HBV genotype $\mathrm{B}$ tends to have higher probability to generate

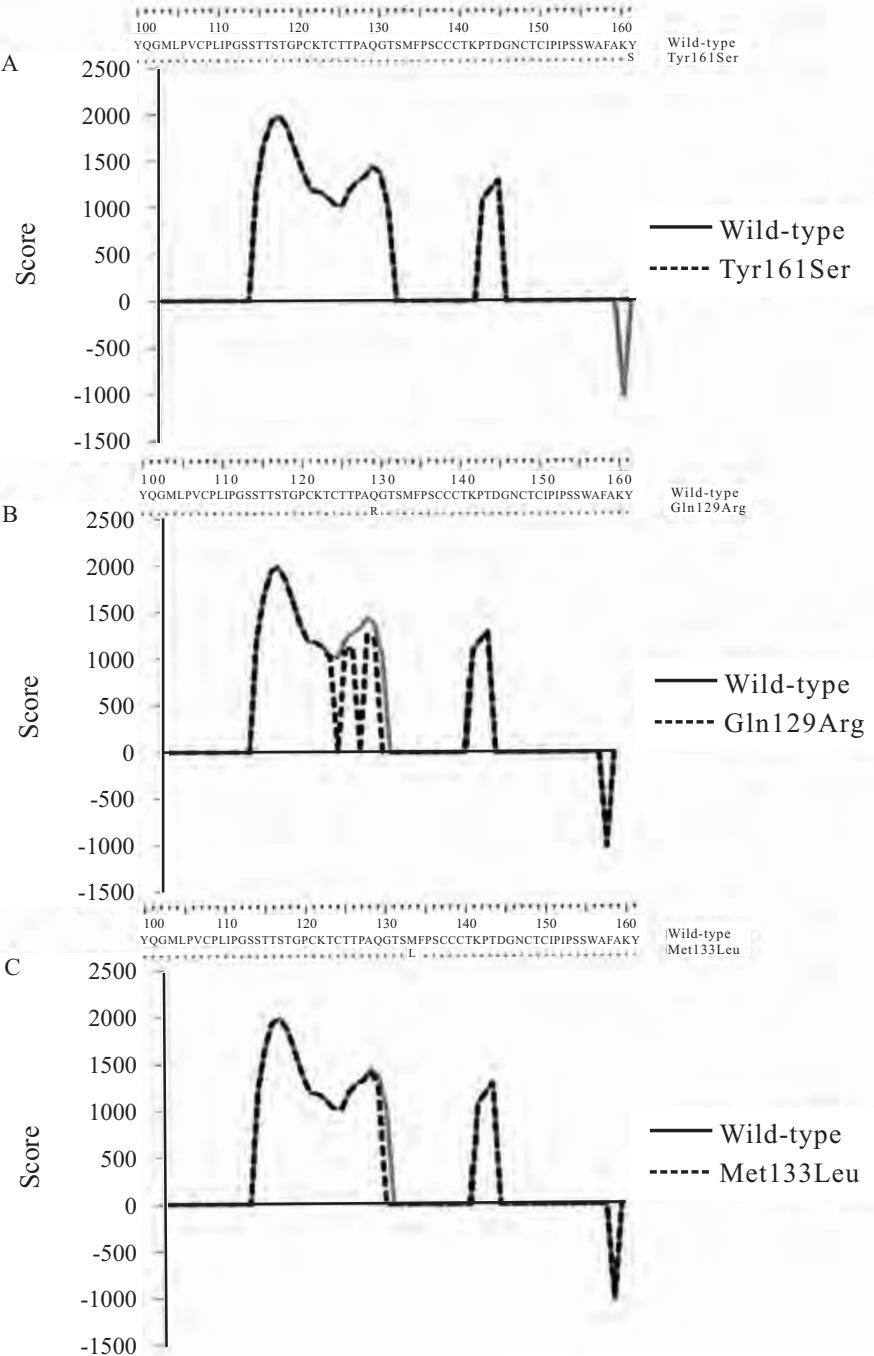

Fig 3 Bepipred linier epitope prediction results from mutant Tyr161Ser (A), Gln129Arg (B), and Met133Leu (C). Mutant Tyr161Ser had different antigenicity score only in amino acid 161 of sHBsAg compared to wildtype, while mutant Gln129Arg showed major antigenicity score difference on amino acid 123-132 of sHBsAg compared to wild-type and Met133Leu gave minor antigenicity score difference on amino acid 128-131 of sHBsAg compared to wild-type.

mutant than genotype C. Mutant Tyr161Ser had been reported before by Sánchez et al. (2002) and Cuestas et al. (2006) from a Mexican and Argentinian patient but was not confirmed as an immune-escape mutant-in contrast to a confirmed-immune-escape mutant Tyr161Leu (Salpini, et al. 2011)-and had not been reported previously from Indonesian patient. Amino acid replacement from tyrosine (uncharged polar amino acid) to leucine (non-polar amino acid) changes antigenicity profile of mutant Tyr161Leu found in sHBsAg that causes immune-escape mutant case. Serine, which replaces tyrosine at Tyr161Ser, is in the same amino acid group with tyrosine. Based on this amino acid characteristic, it is assumed that Tyr161Ser 
may not be an immune-escape mutant, even though further clinical investigation needs to be done.

Based on the B Cell Epitopes Prediction Program, from surface accessibility, antigenicity, hydrophilicity, and linier epitope perspectives, all mutants gave different indices compared to wild-type (Table 1). This difference overall might significantly affect sHBsAg antigenicity (Fig 2) and changes its epitope conformation (Fig 3). Since three-dimensional structure of sHBsAg is still unknown, using prediction tools to determine antigenicity profile change as the effect of amino acid replacements is merely speculative and specific research regarding to antigenicity profile change and clinical immune-escape mutant impact need to be done (Cuestas et al. 2006). However at the Bepipred linier epitope prediction result in Fig 3B, where mutant Gln129Arg showed major antigenicity score difference on amino acid 123-132 of sHBsAg compared to wild-type, this change indicated that mutant's epitope structure may have changed so that binding capacities of this mutant to several monoclonal antibodies were much lower (Chiou et al. 1997).

In brief, this study showed that immune-escape mutant from HBV genotype B, was present in local clinical samples in Indonesia. The amino acid replacement occurred on sHBsAg may change its antigenicity profile. Further study about mutant Tyr161Ser should be done regarding to in vitro study of sHBsAg-anti-sHBs antibody interactions, since it may also be another immune-escape mutant variant.

\section{REFERENCES}

Aljarallah, BM. 2006. Hepatitis B genotyping and its clinical implications. The Saudi J of Gastroenterol. 12(3): 146148.

Carman, WF. 1997. The clinical significance of surface antigen variants of Hepatitis B Virus. J Viral Hepat. (4):S11-20.

Chan HL-Y, Jia JD. 2011. Chronic hepatitis B in Asia-new insights from the past decade. J Gastroenterol Hepatol. 26(S1):131-137. doi:10.1111/j.1440-1746.2010. 06544.x.

Chiou H-L, Lee T-S, Kuo J, Mau Y-C, Ho M-S. 1997. Altered antigenicity of 'a' determinant variants of Hepatitis $B$ Virus. J Gen Virol. 78:2639-2645.

Clements CJ, Coghlan B, Creati M, Locarnini S, Tedder RS, Torresi J. 2010. Global control of Hepatitis B Virus: does treatment-induced antigenic change affect immunization? Bull World Health Organ. 88:66-73. doi:10.2471/BLT.08.065722.

Cuestas ML, Mathet VL, Ruiz V, Minassian ML, Rivero C, Sala A, Corach D, Alessio A, Pozzati M, Frider B,
Oubiňa JR. 2006. Unusual naturally occurring humoral and cellular mutated epitopes of Hepatitis B Virus in a chronically infected Argentine patient with anti-HBs antibodies. J Clin Microbiol. 44(6):2191-2198. doi:10.1128/ JCM.00057-06.

Glebe D. 2007. Pathogenesis of Hepatitis B Virus infection. World J Gastroenterol. 13(1):82-90.

He C, Nomura F, Itoga S, Isobe K, Nakai T. 2001. Prevalence of vaccine-induced escape mutants of Hepatitis $B$ virus in the adult population in China: a prospective study in 176 restaurant employees. J Gastroenterol Hepatol. 16 (12):1373-1377.

Kusumawardhani S. 2009. Kloning dan ekspresi HBsAg isolat Indonesia secara intraselular pada Pichia pastoris KM71 [thesis]. Bandung (ID): Institut Teknologi Bandung.

Lusida MI, Nugrahaputra VE, Soetjipto, Handajani R, Nagano-Fujii M, Sasayama M, Utsumi T, Hotta H. 2008. Novel subgenotypes of Hepatitis B Virus genotypes $\mathrm{C}$ and $\mathrm{D}$ in Papua, Indonesia. J Clin Microbiol. 46(7):2160-2166.

Mast EE, Margolis HS, Fiore AE, Brink EW, Goldstein ST, Wang SA, Moyer LA, Bell BP, Alter MJ. 2005. A comprehensive immunization strategy to eliminate transmission of Hepatitis B Virus infection in the United States. MMWR 54 (RR-16).

Pawlotsky J-M. 2005. The concept of Hepatitis B Virus mutant escape. J Clin Virol. 34:S125-S129.

Purdy MA. 2007. Hepatitis B Virus S gene escape mutants. Asian J Transf Sci. 1(2):62-70.

Salpini R, Cento V, Scopelliti F, Bertoli A, Gori C, Micheli V, Gubertini G, Sanctis GMD, Sarrecchia C, Andreoni M, Svicher V, Perno CF. 2011. Prevalence of drugresistance $H B V$ strains is relatively low in drugexperienced patients and nearly absent in drug-naïve patients [presentation]. Cyprus: European Workshop on HIV and Hepatitis.

Sánchez LV, Maldonado M, Bastidas-Ramīrez BE, Norder H, Panduro A. 2002. Genotypes and S-Gene variability of Mexican Hepatitis B Virus strains. J Med Virol. 68:24-32. doi: 10.1002/jmv.10166.

Thedja MD, Muljono DH, Nurainy N, Sukowati CHC, Verhoef J, Marzuki S. 2011. Ethnogeographical structure of Hepatitis B Virus genotype distribution in Indonesia and discovery of a new subgenotype, B9. Arch Virol. 155:855-868. doi:10.1007/s00705-0110926-y.

Valsamakis A. 2007. Molecular testing in the diagnosis and management of chronic hepatitis B. Clin Microbiol Rev. 20(3):426-439.

Weinberger KM, Bauer T, Bohm S, Jilg W. 2000. High genetic variability of the group-specific a-determinant of Hepatitis B Virus surface antigen (HBsAg) and the corresponding fragment of the viral polymerase in chronic virus carrier Lacking detectable HBsAg in serum. J Gen Virol. (81):1165-1174.

Zainuddin IM. 2008. Kloning dan konstruksi HBsAg ke dalam vektor ekspresi tumbuhan dengan promoter terinduksi luka [thesis]. Bandung (ID): Institut Teknologi Bandung. 
Zumbika E, Ruan B, Xu CH, Ni Q, Hou W, Chen Z, Liu KZ. 2005. $H B V$ genotype characterization and distribution in patients with $H B V$-related liver diseases in Zhejiang Province, PR China: possible association of coinfection with disease prevalence and severity. Hepatobiliary Pancreat Dis Int. 4(4):535-543. 